JURNAL KESEHATAN PENA MEDIKA VOL 10 (1) JUNI 2020

\title{
Studi Kajian Kandungan Bahan
}

\author{
Sujarwo $^{1 凶}$, Vita Nur Latif ${ }^{2}$, Ardiana Priharwanti $^{3}$ \\ ${ }^{1}$ UPT Puskesmas Kusuma Bangsa, DINKES Kota Pekalongan \\ ${ }^{2,3}$ Prodi Kesehatan Masyarakat, Fakultas Ilmu Kesehatan, UNIKAL \\ Email Korespondensi : puskesmaskusumabangsa@gmail.com
}

\begin{abstract}
Food safety Supervision in Pekalongan City in 2010-2012 showed that $6.27 \%$ of food contained hazardous food additives. Additives food are widely used by small industries home food industry. Types of food additives that are often used is Formalin, Borax and textile dyes (Rhodamin B and MethanylYellow). According to Permenkes RI No. 33 of 2012, the four chemicals are prohibited from being used in food products because they are harmful to health. The design of this study is a descriptive study in the form of a case study of the results of food safety surveillance activities in Pekalongan City in 2018-2019. The results of this study identified that the types of food most often found to contain food additives, dangerous preservatives (formalin and borax) were yellow noodles; meatball, indil and cilok; terinasi (Teri Medan); and Otak-otak. The types of food that were most often found to contain food additives harmful dyes (Rhodamin $B$ and Methanil yellow) were red krupuk useg; pudding; powdered seasoning; and yellow krupuk useg.
\end{abstract}

Key words: food safety, type of food, food additive

\begin{abstract}
ABSTRAK
Pengawasan keamanan pangan di Kota Pekalongan tahun 2010-2012 menunjukan hasil $6,27 \%$ pangan mengandung bahan tambahan pangan (BTP) berbahaya. BTP berbahaya paling sering digunakan oleh industri kecil/ industri rumah tangga pangan adalah dari jenis pengawet (Formalindan Boraks)dan jenis pewarna tekstil (Rhodamin $B$ dan MethanylYellow).Menurut Permenkes RI No. 33 Tahun 2012, keempat bahan kimia tersebut dilarang penggunaannya dalam produk pangan karena berbahaya bagi kesehatan.Disain penelitian ini adalah penelitian deskriptif yang berupa studi kasus hasil kegiatan pengawasan keamanan pangan di Kota pekalongan tahun 2018-2019. Hasil penelitian ini teridentifikasi jenispangan paling sering diketemukan mengandung BTP berbahaya pengawet (formalin dan boraks) adalah jenis mie kuning; bakso, indil dan cilok; terinasi (teri Medan); dan otak-otak. Jenis pangan paling sering diketemukan mengandung BTP berbahaya pewarna (Rhodamin B dan Methanil yellow) adalah jenis krupuk useg merah; puding; bumbu bubuk; dan krupuk useg kuning.
\end{abstract}

Kata Kuci : keamanan pangan, Jenis pangan, bahan tambahan pangan (BTP) 


\section{PENDAHULUAN}

Peraturan Pemerintah Republik Indonesia Nomor 86 Tahun 2019 tentang Keamanan Pangan, mendefinisikan bahwa keamanan pangan adalah kondisi dan upaya yang diperlukan untuk mencegah pangan dari kemungkinan cemaran biologis, cemaran kimia, dan benda lain yang dapat mengganggu, merugikan,dan membahayakan kesehatan manusia serta tidak bertentangan dengan agama, keyakinan, dan budaya masyarakat sehingga aman untuk dikonsumsi. Anggrahini, et al, 2015, menjelaskan bahwa pangan dikatakan aman apabila bebas dari bahaya yang mungkin timbul karena adanya kandungan cemaran biologis, kimia dan fisik. Surono et al, 2018, mengartikan bahwa keamanan pangan adalah suatu proses penjaminan pangan dalam proses produksi pengolahan pangan dengan tujuan untuk menyediakan makanan yang aman untuk dikonsumsi. Secara garis besar pangan yang aman adalah pangan yang bebas dari bahaya biologis, bahaya kimiawi dan bahaya fisik (benda asing).

Surono et al, 2018, menjelaskan lebih lanjut bahwa, ancaman bahaya kimiawi biasanya jarang diwaspadai karena dampaknya yang jarang langsung terjadi karena bersifat akumulatif, akan tetapi ada beberapa yang memberikan dampak langsung seperti iritasi pada tenggorokan ataupun gejala penyakit umum lainnya. Ancaman bahaya kimiawi bisa saja berasal dari penggunaan bahan tambahan pangan berizin yang melebihi takaran, bahan kimia berbahaya yang dengan sengaja ditambahankan kedalam pangan seperti zat pengawet (borax dan formalin), zat pewarna (Rhodamin B dan Methanyll Yellow) ataupun bahan peramu lainnya. Rahayu, et al, 2018, menjelaskan bahya Bahan Tambahan Pangan (BTP) berbahaya ini dapat berpengaruh pada gangguan kesehatan baik secara langsung seperti tenggorokan terasa terbakar, iritasi, sakit kepala serta mual, sedangkan pengaruh tidak langsung (menahun/ akumulatif) seperti gangguan sistem pernafasan, gangguan pada ginjal dan hati, gangguan sistem reproduksi dan kangker, serta kematian.

Dinas Kesehatan Kota Pekalongan, 2011-2013,melaporkan hasil kegiatan pengawasan keamanan pangan tahun 2010-2012 menunjukan dari 2.073 sampel pangan yang diperiksa, 6,27\% mengandung BTP berbahaya/ dilarang. 
Badan Pengawasan Obat dan Makanan di Semarang, melaporkanhasil kegiatan pengawasanan keamanan pangan tahun 2018 tentang kegiatan pengawasan pangan dengan sampel Pangan Jajan Anak sekolah (PJAS) bahwa sebanyak 718 sampel di 24 kota/ kabupaten, 0,975\% mengandung BTP berbahaya. Sedangkan di pasar tradisional sebanyak 1.742 sampel di 34 kota/kabupaten 28,59\% mengandung BTP berbahaya (BPOM di Semarang, 2019). Atas dasar inilah peneliti tertarik untuk melakukan studi kajian tentang jenis pangan yang mengandung bahan tambahan pangan berbahaya yang ada di Kota Pekalongan tahun 2018-2019. Tujuan penelitian ini adalah untuk mengidentifikasi lebih lanjut jenis pangan yang mengandung bahan tambahan pangan berbahaya tahun 20182019 di Kota Pekalongan.

\section{METODE PENELITIAN}

Penelitian ini merupakan jenis penelitian Diskriptif (studi kasus) berdasarkan hasil kegiatan pengawasan keamanan pangan di Kota Pekalongan Tahun 2018-2019.Sumber data penelitian ini adalah hasil kegiatan pengawasan keamanan pangan tahun 2018-2019 seKota Pekalongan yang dilakukan oleh Dinas Kesehatan Kota Pekalongan; Dinas Pertanian dan Pangan Kota Pekalongan; Dinas Perdagangan Koperasi dan UMKM Kota Pekalongan. Hasil data dianalisis secara diskriptif menggunakan SPSS kemudian disajikan dalam bentuk diskriptif berupa persentase dan naratif.

\section{HASIL}

Berdasarkan pengumpulan data yang dilakukan selama penelitian, diperoleh hasil sebagai berikut :

\section{1). Beradasarkan Lokasi Sasaran}

Hasil pengumpulan data yang dilakukan peneliti terhadap kegiatan pengawasan keamanan pangan yang dilakukan ke-3 SKPD diperoleh data bahwa sampel pangan yang diperiksa sejumlah 1.286 sampel pangan pada tahun 2018 dan 1.977 sampel pangan pada tahun 2019. Tabel 1 memberikan gambaran lokasi target kegiatan pengawasan keamanan pangan tahun 2018-2019 di Kota Pekalongan 
Tabel 1.Rekap Hasil

Kegiatan Pengawasan Keamanan PanganBerdasarkan Lokasi Sasaran Di Kota PekalonganTahun 2018-2019

\begin{tabular}{|c|c|c|c|c|c|c|c|c|c|}
\hline \multirow{3}{*}{ No } & \multirow{3}{*}{ Lokasi Sasaran } & \multicolumn{4}{|c|}{ Tahun 2018} & \multicolumn{4}{|c|}{ Tahun 2019} \\
\hline & & \multirow[t]{2}{*}{$\begin{array}{l}\text { Jumlah } \\
\text { Sampel }\end{array}$} & \multirow[t]{2}{*}{$(\%)$} & \multicolumn{2}{|c|}{$\begin{array}{c}\text { Sampel } \\
\text { Positif }\end{array}$} & \multirow[t]{2}{*}{$\begin{array}{l}\text { Jumlah } \\
\text { Sampel }\end{array}$} & \multirow[t]{2}{*}{$(\%)$} & \multicolumn{2}{|c|}{$\begin{array}{l}\text { SampelPosit } \\
\text { if }\end{array}$} \\
\hline & & & & $\Sigma$ & $\%$ & & & $\Sigma$ & $\%$ \\
\hline 1 & Sekolahan & 1.021 & 79,40 & 44 & $\frac{4,3^{1}}{3,41^{2}}$ & 1.767 & 89,39 & 91 & $\frac{5,1^{1}}{4,60^{2}}$ \\
\hline 2 & $\begin{array}{l}\text { Event } \\
\text { (Pemeran dll) }\end{array}$ & 172 & 13,37 & 6 & $\frac{3,5^{1}}{0,47^{2}}$ & 120 & 6,06 & 13 & $\frac{10,8^{1}}{0,67^{2}}$ \\
\hline 3 & Pasar Tradisional & 93 & 7,23 & 6 & $\frac{6,5^{1}}{0,47^{2}}$ & 90 & 4,55 & 8 & $\frac{8,9^{1}}{0,40^{2}}$ \\
\hline & Total & 1.286 & 100,00 & 56 & 4,35 & 1.977 & 100,00 & 112 & 5,67 \\
\hline
\end{tabular}

(Sumber : Dinkes, Dinperpa, Dindagkop dan UKM Kota Pekalongan tahun 2018-2019)

Keterangan : (1). \% berdasarkan lokasi dan (2). \% berdasarkan keseluruhan total sampel

Berdasarkan tabel 1 diatas dapat diketahui, kegiatan pengawasan keamanan pangan tahun 2018-2019 di Kota Pekalongan terbagi menjadi 3 lokasi yakni sekolahan, event keramaian kota dan pasar tradisional. Sampel Pangan mengandung BTP berbahaya paling banyak jenis parameter yang diujikan terbagi diketemukan pada tahun 2018 di pasar menjadi 3 jenis yakni jenis pengawet tradisional yakni 6,5\% dan tahun 2019 (boraks dan formalin), jenis pewarna dievent keramaian kota yakni 10,8\% dari (Rhodamin B dan MethanilYellow) dan berdasarkan lokasi pengambilan dan cemaran kimia (Pestisida). pemeriksaan.

\section{2) Berdasarkan Jenis Uji Parameter}

Menurut jenis uji parameter pemeriksaaan yang dilaksanakan dalam kegiatan pengawasan keamanan pangan tersebut terdapat 5 jenis parameter yang diujikan. Tabel 2 memberikan informasi

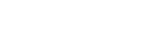

$$
\text { (n) }
$$$$
\text { kimia (Pestisida). }
$$

Tabel 2. Rekap Hasil Kegiatan Pengawasan Keamanan Pangan Berdasarkan

\begin{tabular}{|c|c|c|c|c|c|c|c|c|c|}
\hline \multirow{3}{*}{ No } & \multirow{3}{*}{ Parameter Uji } & \multicolumn{4}{|c|}{ Tahun 2018} & \multicolumn{4}{|c|}{ Tahun 2019} \\
\hline & & \multirow[t]{2}{*}{$\begin{array}{l}\text { Jumlah } \\
\text { sampel }\end{array}$} & \multirow[t]{2}{*}{$(\%)$} & \multicolumn{2}{|c|}{$\begin{array}{c}\text { \% Sampel } \\
\text { positif }\end{array}$} & \multirow[t]{2}{*}{$\begin{array}{l}\text { Jumlah } \\
\text { sampel }\end{array}$} & \multirow[t]{2}{*}{$(\%)$} & \multicolumn{2}{|c|}{$\begin{array}{c}\text { \% Sampel } \\
\text { positif }\end{array}$} \\
\hline & & & & (1) & (2) & & & (1) & (2) \\
\hline 1 & Boraks & 481 & 37,40 & 2,70 & 1,01 & 701 & 35,46 & 0,85 & 0,3 \\
\hline 2 & Formalin & 466 & 36,24 & 4,93 & 1,79 & 706 & 35,71 & 6,37 & 2,28 \\
\hline 3 & Rhodamin B & 257 & 19,98 & 5,83 & 1,17 & 405 & 20,49 & 8,14 & 1,67 \\
\hline 4 & Methanil $Y$ & 45 & 3,50 & 11,11 & 0,39 & 135 & 6,83 & 20,00 & 1,37 \\
\hline 5 & Pestisida & 37 & 2,88 & 0 & 0 & 30 & 1,52 & 3,33 & 0,05 \\
\hline & Total & 1.286 & 100,00 & - & 4,35 & 1.977 & 100,00 & - & 5,67 \\
\hline
\end{tabular}
Parameter Uji Di Kota Pekalongan Tahun 2018-2019 
(Sumber : Dinkes, Dinperpa, Dindagkop dan UKM Kota Pekalongan tahun 2018-2019)

Berdasarkan tabel 2dapat diketahui, diketemukan adalah kandungan Formalin parameter yang paling banyak diujikan pada tahun 2018 adalah boraks, Formalin dan Rhodamin $B$. Berdasarkan jenis parameter yang diujikan, kandungan BTP berbahaya pada sampel pangan yang $1,79 \%$ pada tahun 2018 dan $2,28 \%$ pada tahun 2019.

\section{3). Berdasarkan Jenis Pangan}

Menurut jenis pangan yang paling sering diketemukan adalah diketemukan positif mengandung BTP kandungan Methanil Yellow 11,11\% pada berbahaya, terdapat 57 jenis pangan. tahun 2018 dan 20,00\% pada tahun 2019 dari berdasarkan jenis parameter yang Tabel 3 memberikan informasi jenis pangan yang paling sering diketemukan mengandung BTP berbahaya dari diujikan. Jika berdasarkan total keseluruhan total sampel yang diperiksa keseluruhan sampel pangan yang dalam kegiatan pengawasan keamanan diperiksa, kandungan BTP berbahaya pangan tahun 2018-2019 di Kota pada sampel pangan yang paling sering Pekalongan.

Tabel 3. Rekap Prosentase Jenis Pangan Positif Mengandung Bahan Tambahan Pangan Berbahaya Di Kota PekalonganTahun 2018-2019

\begin{tabular}{|c|c|c|c|c|c|c|c|}
\hline \multirow[b]{2}{*}{ No } & \multirow[b]{2}{*}{ Jenis Pangan } & \multicolumn{2}{|c|}{ Prosentase (\%) } & \multirow[b]{2}{*}{ No } & \multirow[b]{2}{*}{ Jenis Pangan } & \multicolumn{2}{|c|}{ Prosentase (\%) } \\
\hline & & $\begin{array}{c}\text { Tahun } \\
2018 \\
\end{array}$ & $\begin{array}{c}\text { Tahun } \\
2019 \\
\end{array}$ & & & $\begin{array}{c}\text { Tahun } \\
2018 \\
\end{array}$ & $\begin{array}{c}\text { Tahun } \\
2019 \\
\end{array}$ \\
\hline 1 & Mie goreng & 3,57 & 4,46 & 30 & Opak angin & 1,78 & \\
\hline 2 & Mie kuning & 10,71 & 14,29 & 31 & Minuman & 3,67 & 1,77 \\
\hline 3 & Mie Gulung & - & 1,79 & 32 & Bakso, indil, cilok & 14,27 & 3,57 \\
\hline 4 & Nuget mie & - & 0,89 & 33 & Cireng & 1,78 & 0,89 \\
\hline 5 & Tahu balado & - & 0,89 & 34 & Gereh sotong & - & 0,89 \\
\hline 6 & Tahu bulat & - & 0,89 & 35 & Nuget & 1,78 & 1,79 \\
\hline 7 & Tahu crispi & 3,57 & & 36 & otak-otak & $\mathbf{5 , 3 5}$ & \\
\hline 8 & Tahu goreng & - & 1,79 & 37 & Scalep & - & 0,89 \\
\hline 9 & Tahu kopyok & - & 0,89 & 38 & Sempolan & 3,57 & 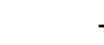 \\
\hline 10 & Tahu kulit & - & 0,89 & 39 & Sosis & 1,78 & 2,68 \\
\hline 11 & Tahu bacem & 1,78 & - & 40 & Sosis gulung mie & - & 0,89 \\
\hline 12 & Tahu putih & 1,78 & 2,68 & 41 & Tahu bakso & 1,78 & 0,89 \\
\hline 13 & Tahu sakura & 0 & 1,79 & 42 & Terinasi (teri medan) & 5,35 & 1,79 \\
\hline 14 & Tepung panir & - & 0,89 & 43 & Arum manis & 1,78 & 2,68 \\
\hline 15 & Bumbu bubuk & - & 6,25 & 44 & Jipang & - & 0,89 \\
\hline 16 & Mesis & - & 0,89 & 45 & Kembang kapas & - & 0,89 \\
\hline 17 & Tepung panir & - & 0,89 & 46 & Permen karet & 1,78 & 0,89 \\
\hline 18 & Biting bumbu & - & 0,89 & 47 & Permen tengkorak & - & 0,89 \\
\hline 19 & Contong es merah & - & 0,89 & 48 & Manisan & - & 0,89 \\
\hline 20 & Intip & 1,78 & - & 49 & Tomat & - & 0,89 \\
\hline 21 & Krupuk Gendar & - & 0,89 & 50 & Agar-agar & 3,57 & 1,79 \\
\hline 22 & Krupuk rambak & 3,57 & - & 51 & Ala nyam-nyam & 3,57 & \\
\hline 23 & Krupuk tepi kuning & - & 2,68 & 52 & Kue ku & - & 1,79 \\
\hline 24 & Krupuk tepi merah & 3,57 & 1,79 & 53 & Lumpia & - & 0,89 \\
\hline
\end{tabular}




\begin{tabular}{llrrrlrrr}
25 & Krupuk useg kuning & - & $\mathbf{5 , 3 6}$ & & 54 & Martabak & 1,78 & 1,79 \\
26 & Krupuk useg merah & 3,57 & $\mathbf{1 0 , 7 1}$ & & 55 & Mie gulung & - & 1,79 \\
27 & Krupuk usus & - & 1,79 & & 56 & Pop corn & 1,78 & 0,89 \\
28 & Makaroni goreng & 1,78 & 0,89 & & 57 & Puding & $\mathbf{7 , 1 4}$ & 3,57 \\
\hline & 1,78 & - & & & Jumlah & $\mathbf{1 0 0 \%}$ & $\mathbf{1 0 0 \%}$ \\
\hline
\end{tabular}

(Sumber : Dinkes, Dinperpa, Dindagkop dan UKM Kota Pekalongan tahun 2018-2019)

Berdasarkan tabel 3 dapat dilihat tahun yellow) adalah jnis krupuk useg warna 2018, berdasarkan dari sampel pangan merah; bumbu bubuk; dan puding. yang positif mengandung BTP berbahaya, Jenis pangan yang paling sering yang paling sering diketemukan adalah diketemukan positif mengandung BTP pangan jenis : jenis bakso, indil dan cilok $(14,27 \%)$; jenis mie kuning (10,71\%); jenis puding $(7,14 \%)$; dan jenis terinasi dan otak-otak (5,35\%). Tahun 2019, berdasarkan sampel pangan yang positif mengandung BTP berbahaya, yang paling sering diketemukan adalah pangan jenis : jenis mie kuning (14,29\%); krupuk useg warna merah (10,71\%); jenis bumbu bubuk (6,28\%); dan jenis krupuk useg warna kuning $(5,36 \%)$.

\section{PEMBAHASAN}

Pada penelitian ini diketahui bahwa jenis pangan yang paling sering diketemukan mengandung BTP berbahaya sebagai berikut yakni jenis pangan yang paling sering diketemukan mengandung BTP berbahaya pengawet (formalin dan boraks) adalah jenis mie kuning (mie basah); jenis bakso, indil dan cilok; jenis terinasi (teri Medan); dan jenis otak-otak. Jenis pangan yang paling sering diketemukan mengandung BTP berbahaya pewarna (Rhodamin $B$ dan Methanil berbahaya dari total sampel pangan yang positif, pada tahun 2018 adalah pangan jenis : $12,50 \%$ bakso, indi dan cilok mengandung boraks; $10,71 \%$ mie kuning mengandung formalin; 7,14\% puding mengandung Rhodamin $B$ dan Methanil Yellow; 5,36\% terinasi (teri medan) mengandung formalin; dan 5,36\% otakotak mengandung formalin dan Rhodamin B. Sedangkan pada tahun 2019 jenis pangan yang paling sering diketemukan mengandung BTP berbahaya adalah pangan jenis : $12,50 \%$ mie kuning mengandung formalin; 11,61\% krupuk useg warna merah mengandung Rhodamin $B ; 6,25 \%$ bumbu bubuk mengandung Methanil Yellow; dan 4,46\% krupuk useg warna kuning mengandung Methanil Yellow.Idealnya pangan yang beredar/ dijual haruslah memenuhi kriteria pangan, yakni : aman, bermutu dan bergizi. Pangan yang aman untuk dikonsumsi adalah pangan yang bebas dari cemaran fisik, cemaran biologi dan cemaran kimia. 
Salah satu aspek aman dari cemaran kimia adalah terbebas dari bahan tambahan pangan berbahaya/dilarang ditambahkan pada pangan. Pangan yang aman untuk dikonsumsi adalah pangan yang bebas dari cemaran fisik, cemaran biologi dan cemaran kimia. Salah satu aspek aman dari cemaran kimia adalah terbebas dari bahan tambahan pangan (BTP) berbahaya/ dilarang ditambahkan pada pangan.

Penggunaan BTP berbahaya tersebut dilarang ditambahkan pada pangan karena dapat menyebabkan gangguan kesehatan baik jangka pendek mupun jangka panjang. Menurut Peraturan Menteri Kesehatan Republik Indonesia Nomor 33 Tahun 2012 tentang Bahan Tambahan Pangan dan Peraturan Daerah Kota Pekalongan Nomor 07 Tahun 2013 tentang Larangan Penggunaan Bahan Tambahan Pangan Berbahaya, keempat bahan kimia tersebut dilarang penggunaannya dalam produk pangan karena berbahaya bagi kesehatan.

\section{a). Formalin}

Sajiman et al, 2015, lebih lanjut menjelaskan bahwa formalin dapat merusak sistem persyarafan tubuh manusia yang bersifat racun untuk persyarafan (neurotoksik) dan dapat mengganggu sistem organ reproduksi seperti kerusakan testis ataupun ovarium, gangguan menstruasi serta dapat mengganggu infertilitas sekunder.

\section{b). Boraks}

Pongsavee (2009) seperti dikutip dalam Nurhamida, (2019), menerangkan lebih mendalam bahwa tingkat toksisitas boraks tergantung pada dosis atau konsentrasi boraks yang masuk kedalam tubuh. Bagian yang paling berdampak pada tubuh akibat mengkonsumsi pangan mengandung boraks adalah saluran pencernaan, kulit, pembuluh darah dan otak. Hal tersebut dapat menimbulkan tanda gejala berupa mual muntah yang berkepanjangan, sakit perut dan diare.

\section{c).Rhodamin B}

Surati, 2015, menjelaskan lebih mendalam bahwa bahaya utama terhadap kesehatan akibat konsumsi pangan yang mengandung Rhodamin $B$ dalam waktu lama bersifat kronis, yang dapat menyebabkan radang kulit alergi, dan gangguan fungsi hati/kanker hati

\section{d). Methanyl Yellow}

Kristanti (2010) dalam kutipan Zuraida, et al (2017) menjelaskan bahwa dampak negatif yang terjadi akibat mengkonsumsi pangan yang mengandung zatMethanil Yellow dapat 
berupa iritasi pada tenggorokan tambahan pangan berbahaya untuk semua (saluran pernafasan), iritasi pada kulit, sampel yang diteliti. Sehingga jajanan iritasi pada mata, dan bahaya kanker anak di sekolah area Sidorejo Kidul masih pada kandung kemih. Bahaya lebih dapat dikatakan aman untuk dikonsumsi. lanjut yakni menyebabkan kanker pada Hal ini dimungkinkan karena penelitian kandung kemih dan saluran kemih. $\quad$ yang dilakukan hanya pada tingkatan Hasil penelitian ini sejalan dengan temuan sekolah dasar se-wilaya saja, dan jumlah ini BPOM di Semarang tahun 2018, sampel yang diperiksa lebih sedikit. bahwa hasil pengawasan pangan sampel Sedangkan pada penelitian ini data yang Pangan Jajan Anak sekolah (PJAS) diperoleh dari hasil kegiatan pengawasan sebanyak 718 sampel di 24 kota/ keamanan pangan di Kota Pekalongan kabupaten, 0,975\% positif mengandung lokasi yang menjadi sasaran adalah semua BTP berbahaya, artinya terindikasi bahwa 24 kota/ kabupaten di Provinsi Jawa Tengah beredar pangan jajan anak sekolah yang mengandung BTP berbahaya.

Hasil penelitian ini diperkuat dengan penelitian yang dilakukan oleh Paratmanitya dan Aprilia, 2016, juga menyatakan bahwa jenis makanan didugamengandung bahan kimia berbahaya paling banyak dijajakan di SD adalah jenis bakso (bakso, baksotusuk, bakso goreng) yaitu sejumlah 22,4\% dari seluruh sampel jajanan, diantara sampel yang diuji: $15,3 \%$ positif boraks; $25,5 \%$ positif formalin; 46,7\%) positif Rhodamin $B$.

Hasil penelitian ini, bertolak belakang dengan penelitian Nurdin dan Utomo, 2018, yang dalam penelitiannya menyatakan bahwa tidak ditemukan bahan sekolahan dari mulai tingkatan SD dan MI hingga tingkatan $\mathrm{SMA} / \mathrm{K}$ dan $\mathrm{MA}$, serta lokasi lain seperti pasar tradisional dan event keramaian kota. Hal ini diperkuat juga dengan jumlah sampel pangan yang diperiksa lebih banyak dan jenis pangan sampel yang diperiksa lebih variatif.

Hasil penelitian ini merujuk jenis pangan yang paling sering diketemukan mengandung BTP berbahaya jenis pengawet adalah pangan jenis bakso, indil dan cilok; mei kuning; terinasi (terimedan); dan otak-otak. Sedangkan merujuk jenis pangan yang paling sering diketemukan mengandung BTP berbahaya jenis pewarna adalah pangan jenis krupuk useg warna merah; bumbu bubuk; krupuk useg warna kuning; dan puding. Penambahan BTP berbahaya jenis pengawet (formalin dan boraks) 
kemungkinan karena jenis pangan tersebut adalah jenis pangan yang apabila disajikan dalam keadaan normal (penyimpanan suhu ruangan) merupakan jenis pangan yang akan cepat basi, cepat tengik dan berbau, sehingga apabila jenis pangan tersebut dijual dan tidak cepat habis terjual maka hal tersebut dapat merugikan penjual. Kemungkinan untuk mengelabui agar pangan tersebut tetap awet dalam jangka waktu yang cukup lama, kemungkinan produsen pangan menambahkan BTP berbahaya tersebut kedalam proses produksinya, seperti yang ada dalam penelitian ini bahwa jenis pangan yang paling sering dijumpai mengandung BTP berbahaya jenis pengawet adalah jenis : mie kuning (mie basah yang biasa digunakan pada pangan bakso ataupun mie goreng/ rebus); bakso, indil dan cilok; terinasi (teri medan); dan otak-otak. Penambahan BTP berbahaya jenis pewarna (Rhodamin $B$ dan MethanilYellow) kemungkinan ditambahkan pada pangan adalah untuk lebih menarik tampilan pangan. Penggunaan pewarna pangan sebetulnya diperbolehkan dengan menggunakan pewarna pangan yang diijinkan dan sesuai dengan takarannya, yang sudah diatur oleh undang-undang, tetapi kemungkinan penambahan BTP berbahaya jenis ini dalah memberikan warna yang lebih kuat, harga lebih murah sehingga mampu memberikan keuntungan lebih dalam penjualan. Seperti yang ada dalam penelitian ini bahwa jenis pangan yang paling sering diketemukan mengandung BTP berbahaya jenis pewarna adalah jenis :Krupuk useg warna merah, bumbu bubuk, krupuk useg warna kuning dan puding.

Jenis pangan yang mengandung BTP berbahaya tersebut sebetulnya dapat dikenali secara fisik. Pangan yang mengandung BTP berbahaya pengawet (formalin dan boraks) dapat dilihat meliki ciri : tekstur lebih kenyal (pada bakso, indil dan cilok; dan otak-otak), warna cenderung pucat keabu-abuan (pada bakso, indil dan cilok), lebih elastis/ tidak cepat putus jika ditarik (pada mie kuning), tidak dihinggapi lalat (pada jenis terinasi dan bakso), berbau tidak normal/ bukan khas bau pangan dan memiliki waktu simpan lebih dari 4-6 jam (pada mie kuning)/ waktu simpan lebih dari 1-2 hari (pada jenis bakso, indil dan cilok; dan otak-otak) atau sampai beberapa bulan pada terinasi (teri Medan). Pangan yang mengandung BTP berbahaya pewarna (Rhiodamin B dan Methanil Yellow) dapat dilihat memiliki ciri : warna pangan yang cenderung berpendar (pada snack dan 
minuman) dan memberikan titik-titik warna pada pangan karena tidak homogen (pada krupuk).

Hasil penelitian ini juga menemukan adanya bahan kimia berbahaya lainnya yang mungkin ada pangan, tetapi bukan jenis BTP berbahaya, yakni kandungan pestisida pada pangan. Jenis pangan yang diketemukan mengandung pestisida pada penelitian ini adalah jenis sayur dan buah, yakni tomat. Berdasarkan total sampel pangan yang diperiksa, $0,05 \%$ positif mengandung pestisida. Seharusnya kandung pastisida pada pangan tidak boleh ada, apalagi ini merupakan jenis sayur yang bisa saja mungkin langsung dikonsumsi tanpa melalui proses pengolahan terlebih dahulu. Diklat

Fungsional Penyuluh Kemanan Pangan, 2017, menerangkan bahwa Ancaman bahaya kimiawi juga bisa berasal dari sisa residu pestisida yang penggunaannya secara sembrono sehingga kemungkinan menempel pada bahan baku pangan dan kemungkinan adanya endapan logam berat dari kondisi lingkungan yang tercemar yang terakumulasi dalam pangan.

\section{SIMPULAN dan SARAN}

Berdasarkan hasil dan pembahasan yang sudah dilakukan, maka dapat disimpulkan bahwa : Teridentifikasi lebih lanjut jenis pangan yang mengandung
BTP berbahaya di Kota Pekalongan tahun 2018-2019 bahwa jenis pangan yang paling sering diketemukan mengandung BTP berbahaya pengawet (formalin dan boraks) adalah jenis mie kuning (mie basah); jenis bakso, indil dan cilok; jenis terinasi (teri Medan); dan jenis otak-otak. Jenis pangan yang paling sering diketemukan mengandung BTP berbahaya pewarna (Rhodamin B dan Methanil yellow) adalah jenis krupuk useg warna merah; Puding; bumbu bubuk; dan krupuk useg warna kuning. Sedangkan pangan yang diketemukan mengandung pestisida adalah jenis tomat.

Berdasarkan penarikan kesimpulan yang ada, maka dapat disarankan sebagai berikut :

1). Pemerintah Kota Pekalongan, melalui Bappeda dapat melaksanakan kegiatan pengawasan keamanan pangan secara rutin dan terpadu.

2). Pemerintah Kota Pekalongan, melalui Bappeda dapat melakukan kegiatan komunikasi informasi dan edukasi tentang pangan yang aman ke pada masyarakat oleh SKPD (Satuan Kerja pemerintah Daerah) yangsesuai dengan tugas pokok dan fungsinya.

3). Produsen pangan/ penjual pangan yang ada di Kota Pekalongan harus memproduksi/ menjual pangan yang aman 
dari cemaran bahan kimia, khusunya aman dari penggunaan BTP berbahaya.

\section{TERIMA KASIH}

Dengan ini disampaikan terima kasih kepada :

1. Bapak Dr. Slamet Budiyanto, SKM, M.Kes selakuKepala Dinas Kesehatan Kota Pekalongan atas pemberian ijin lokasi penelitian serta atas ijin belajar yang diberikan.

2. Bapak Zainul Hakim,SH,M.Hum selaku Kepala Dinas Pertanian dan Pangan Kota Pekalongan, atas ijin lokasi penelitian

3. Bapak Bambang Nurdiyatmo, SH selaku Kepala Dinas Perdagangan Koperasi dan UMKM Kota Pekalongan atas ijin lokasi penelitian

\section{DAFTAR PUSTAKA}

Anggiarini, N.A.,L. Hanim, dan U. Ma'ruf. 2018. Studi Pelaksanaan Kebijakan Pemerintah Daerah Terkait Bahan Tambahan Pangan Pada Jajanan AnakSekolah Menurut Permenkes No. 033 Tahun 2012 di Kabupaten Jepara. Semarang. Jurnal Hukum Khaira Ummah Volume 13 (1), Maret $2018: 215-228$. (online). Diunduh tanggal 26 September 2018. http://jurnal.unissula.ac.id

Anggrahini, S. 2015. Kemanan Pangan. Jakarta. PT Kasinus

Athaya, Z. R., E. Elmatris, dan H. Kadri. 2015. Identifikasi Boraks pada
Cincau Hitam yang Diproduksi Beberapa Produsen Cincau Hitam di Kota Padang. Padang. Jurnal Kesehatan Andalas Volume 3 (1), Tahun 2015: 37-40. Diunduh tanggal $10 \quad$ Agustus 2020. http://jurnal.fk.unand.ac.id

BPOM di Semarang. 2017. Modul Pendidikan dan Pelatihan Fungsional Penyuluh Keamanan Pangan Tahun 2017. Semarang. BPSDM Prov Jateng.

2019. Laporan

Tahunan BPOM di Semarang Tahun 2018. Badan Pengamanan Obat dan Makanan Republik Indonesia. https://pom.go.id, diakes tanggal 02 Februari 2020.

Chaudhur. 2015. Food Safety: A Public Health Priority. Indian Journal of Public Health, Volume 59, Issue 2, April-June, 2015. Diunduh tanggal 05 Februari 2020. http://www.ijph.in.

Dinkes Kota Pekalongan. 2011. Laporan Tahunan Dinas Kesehatan Kota Pekalongan Tahun 2010. Dinas Kesehatan Kota Pekalongan

2012. Laporan

Tahunan Dinas Kesehatan Kota Pekalongan Tahun 2011. Dinas Kesehatan Kota Pekalongan 2013. Laporan Tahunan Dinas Kesehatan Kota Pekalongan Tahun 2012. Dinas Kesehatan Kota Pekalongan

Estiasih, T., W.D.R Putri, dan E. Widyastuti. 2015. Komponen Minor dan Bahan Tambahan Pangan. Jakarta. PT.Bumi Aksara 
Handayani, S, dan H. Hartono. 2016.Hubungan PengetahuanGuru dan PengelolaKantinTentang Gizi BTP, TerhadapPenggunaan BTP Beresikopada Makanan Anak SD diSurakarta. Jurnal Terpadu Ilmu Keehatan, Volume 5 (2) Tahun 2016: 110-237.http://jurnal.poltekkessolo.ac.id

Istiqomah, S.,M.B Sudarwanto, dan E. Sudarnika $^{(3)}$ et al. 2016. Penambahan Boraks dalam Bakso dan Faktor PendorongPenggunaannya Bagi Pedagang Bakso di Kota Bengkulu. Jurnal Sain Veteriner,Volume 34 (1) Tahun 2016. Diunduh tanggal 10 Agustus 2020. http://jurnal.ugm.ac.id

Kholid, A. 2012. Promosi Kesehatan dengan Pendekatan Teori Perilaku, Media dan Aplikasinya. Jakarta. Rajawali Pers

Laksmita, A.S.W., N.P Widayanti, dan M.A.F Refi.2018. Identifikasi Rhodamin B Dalam Saus Sambal yang Beredar Di Pasar Tradisional Dan Modern Kota Denpasar. Jurnal Media Sains Volume 2 (1) Tahun 2018: $8-$

13.http://jurnal.undhirabali.ac.id

Nuraini,

S.

2016.Analisis

KandunganBahan

TambahanDilarang Pada Pangan

JajananAnak Sekolah (PJAS) di Sekolah Dasar Kecamatan RajabasaKota Bandar Lampung. Jurnal Analis Kesehatan,Volume 5 (1) Tahun 2016: 490-493. http://ejournal.poltekkes-tjk.ac.id

Nurdin, N, dan U. Budi. 2018. Tinjauan Penggunaan Bahan Tambahan Pangan Pada Makanan Jajanan Anak Sekolah. Jurnal Riset Kesehatan, Volume 7 (2) Tahun
2018: 85-90. Diunduh tanggal 31 Oktober 2019. http://ejournal.poltekkes-smg.ac.id

Nurhamida, N. 2019. Kandungan Bahan Kimia Berbahaya pada Bakso di Kota Bogor Tahun 2015-2017 (Studi Kasus). Skripsi. Fakultas Kedokteran Hewan Institut Pertanian Bogor (IPB). Bogor

Paratmanitya, Y, dan V. Aprilia. 2016. Kandungan bahantambahan panganberbahaya padamakanan jajanan anak sekolahdasar di KabupatenBantul. Jurnal Gizi dan Dietetik Indonesia, Volume 4 (1) Tahun 2016: 49-55. Diunduh Tanggal 31 Oktober 2019. http://ejournal.almaataa.ac.id

Peraturan Badan Pengamanan Obat dan Makanan Nomor 11 Tahun 2019 Bahan Tambahan Pangan. 01 Juli 2019. Berita Negara Republik Indonesia Tahun 2019 Nomor 723. Jakarta

Peraturan Daerah Kota Pekalongan Nomor 07 Tahun 2013 Larangan Penggunaan Bahan Tambahan Pangan Berbahaya. 29 Juli 2013. Lembaran Daerah Kota Pekalongan Tahun 2013 Nomor 7. Kota Pekalongan

Peraturan Menteri Kesehatan Republik Indonesia Nomor 33 Tahun 2012 Bahan Tambahan Pangan. 01 Maret 2012. Lembaran Negara republik Indonesia Tahun 2012 Nomor 58. Jakarta

Peraturan Pemerintah Republik Indonesia Nomor 86 Tahun 2019 Kemanan Pangan. 26 Desember 2019. Lembaran Negara republik Indonesia Tahun 2019 Nomor 249. 
Tambahan Lembaran Negara Republik Indonesia Tahun 2019 Nomor 6442. Jakarta

Radar Pekalongan. 2019. Produksi Mie Basah Berformalin Diungkap. Sabtu, 14 Desember 2019.

Rahayu, P.W, dan I. Susalit. 2018. Keamanan Pangan Kepedulian Kita Bersama. Bogor. PT Penerbit IPB Perss.

Rakes, S.P., R. Thiagesan, dan R. Ramachandran. 2017. A Point Source Outbreak of Acute Gastroenteritis among School Students in Kerala, India. Indian J Public Health 2017;61:302-4. Diunduh tanggal 05 Februari 2020. http://www.ijph.in.

Rofieq, A., E.P. Dewangga, dan M.H Lubis. 2017. Analisis Bahan Tambahan Pangan Berbahaya Dalam Jajanan Di Lingkungan Sekolah Menengah Atas Propinsi Jawa Timur Indonesia. Prosiding Seminar Nasional III Tahun 2017Universitas Muhamadiyah Malang "Biologi, Pembelajaran, dan Lingkungan Hidup Perspektif Interdisipliner": 75-83. Malang, 29 April 2017. Diunduh tanggal 09 Oktober 2018.http://researchreport.umm.ac.id

Sahani .W, dan J. Yuni. 2017. Kandungan Zat Pewarna Metanil Yellow pada Tepung Panir yang Dijual di Pasar Tradisional Kota Makassar. Jurnal Sulolipu : Media Komunikasi Sivitas Akademika dan Masyarakat Volume 17 (1) Tahun 2017: 56-59. Diunduh tanggal 10 Agustus 2020. http://journal.poltekkes-mks.ac.id
Sajiman, Nurhamidi, dan Mahpolah. 2015. Kajian Bahan Berbahaya Formalin, Boraks, Rhodamin B dan 'yn Yellow pada Pangan Jaj، ak Sekolah Di Banjarbaru. Jurnal Skala Kesehatan Volume 6 (1) Tahun 2015. Diunduh tanggal 10 Agustus 2020. https://ejurnalskalakesehatanpoltekkesbjm.com

Sharma, B., dan K. Satinder. 2015. Microbial Evaluation of Bottled Water Marketed in North India. Indian J Public Health 2015;59:299301. Diunduh tanggal 05 Februari 2020. http://www.ijph.in.

Surati. 2015.Bahaya Zat Aditif Rhodamin $B$ pada Makanan. Biologi SKL Volume 4 (1). Tahun 2015: 22-28. Diunduh tanggal 10 Agustus 2020. http://Jurnal.iainambon.ac.id

Surono, I.S., A. Sudibyo, dan P. Waspodo. 2018. Pengantar Keamanan Pangan untuk Industri. Yogyakarta. Penerbit Deepublish

Undang-undang Republik Indonesia Nomor 18 Tahun 2012 Pangan. 16 November 2012. Lembaran Negara republik Indonesia Tahun 2012 Nomor 227. Jakarta

Wijaya, H., N.Mulyono, dan F.A.Afandi. 2018. Bahan Tambahan Pangan Pengawet. Bogor. PT Penerbit IPB Perss.

Yulisa, N.Y., E. Asni, dan M. Azrin. 2014. Uji Formalin pada Ikan Asin Gurami di Pasar Tradisional Pekanbaru. Jom FK Volume 1 (2) Oktober 2014. Diunduh tanggal 10 Agustus 2020. https://media.neliti.com 
Zuraida, R., O. Saputra., Z. Sahli, dan A.Aprilia2017. Faktor-Faktor yang Mempengaruhi Pedagang Jajanan Anak Sekolah Dasar terhadap Penggunaan Pewarna Metanil Yellow di Kecamatan Sukarame Bandar Lampung Tahun 2015. Jurnal Kesehatan dan Agromedicine Volume 4 (1). Tahun 2017. https://juke.kedokteran.unila.ac.id 